\title{
Vegetative development, primary and secondary growth of the shoot system of young Terminalia superba tropical trees, in a natural environment. I. Spatial variation in structure and size of axes
}

\author{
E de Faÿ \\ Université de Nancy I, Laboratoire de biologie des Ligneux, BP 239, \\ 54506 Vandouvre-lès-Nancy Cedex, France
}

(Received 21 August 1991; accepted 17 April 1992)

\begin{abstract}
Summary - Spatial variations in trunk structure including wood histology and size of axes were examined in 521 -month-old Terminalia superba Engl and Diels trees, grown in a natural tropical environment. Long and shorter internode series alternated along the main axes, forming rather poorly delimited units of extension. In trunk wood, the paratracheal axial parenchyma of the confluent type formed irregular bands, the spacing of which varied gradually, increasing and decreasing alternately. These widely- and narrowly- spaced parenchyma bands differentiated various wood layers. The radial enlargement and wall thickness of fibres also varied in the same manner, as did, but to a lesser extent, the width of parenchymal bands, the radial enlargement of parenchyma cells and vessels, and the wall thickness of vessels. The number of various wood layers in trunk segments that were defined by variations in internodal length was not related to the order of appearance of the trunk segments in question. These results suggest that trunk wood exhibited alternating dense and not very dense wood layers, but they did not provide visible structural evidence of a well-pronounced growth periodicity in the main shoot of Terminalia superba. The existence of a structural discontinuity in the peripheral wood and the significance of the basipetal differentiation of the outermost adjacent wood layer have been discussed in relation to seasonal changes in climate and phenology. On the other hand, trunk thickness increased markedly from $5 \mathrm{~cm}$ above to $5 \mathrm{~cm}$ beneath the upper pseudowhorls of branches. The thickness of axes (branches and trunks) was closely related to the number of sympodial units located in a centrifugal and an upper position respectively. Moreover, a pseudowhorl of branches was generally inserted in the middle part of trunk segments defined by variations in internodal length. These data indicate trunk-branch correlations. It is suggested that some structural variations in trunk wood could be related to branching.
\end{abstract}

radial size / structural unit / Terminalia superba / tropical tree / wood

Résumé - Développement végétatif, croissance primaire et secondaire du système caulinaire de jeunes arbres tropicaux de l'espèce Terminalia superba, dans un environnement naturel. I. Variation dans l'espace de la structure et de la dimension des axes. Les variations dans l'espace de la structure du tronc - y compris l'histologie du bois - et de la dimension des axes furent examinées chez 5 plants de Terminalia superba Engl et Diels âgés de 21 mois et poussant dans un environnement naturel tropical. Des séries d'entre-nœuds longs et plus courts alternaient le long des 
axes principaux formant des unités de croissance mal délimitées. Dans le bois des troncs, le parenchyme axial paratrachéal, de type confluent, formait des bandes irrégulières dont l'espacement variait graduellement, augmentant et diminuant en altemance. Ces bandes de parenchyme largement et faiblement espacées différenciaient des couches de bois. La dilatation radiale et l'épaisseur des parois des fibres variaient aussi de la même manière que précédemment. Il en était de même, quoique à un moindre degré, de l'épaisseur des bandes de parenchyme, de la dilatation radiale des cellules parenchymateuses et des vaisseaux, et de l'épaisseur des parois des vaisseaux. Le nombre de couches de bois dans les segments de tronc définis par des variations dans la longueur des entre-nœuds n'était pas lié à l'ordre d'apparition des segments en question. Tous ces résultats suggèrent que le bois des troncs présentait des couches alternativement denses et peu denses, mais ils ne donnent pas de preuve structurale d'une périodicité de croissance bien marquée dans la flèche des Terminalia superba. L'existence d'une discontinuité structurale dans le bois périphérique et la signification de la couche de bois adjacente la plus externe sont discutées en relation avec les changements de saison et de phénologie. Par ailleurs, l'épaisseur des troncs s'accroissait de façon marquée de $5 \mathrm{~cm}$ audessus à $5 \mathrm{~cm}$ en-dessous des étages supérieurs de branches. L'épaisseur des axes (branches et troncs) était étroitement liée au nombre d'unités sympodiales en position respectivement centrifuge et supérieure. De plus, un étage de branches était généralement inséré dans la partie médiane des segments de tronc définis par des variations dans la longueur des entre-nœuds. Ces données attirent l'attention sur les corrélations entre branches et tronc. Il est suggéré que des variations structurales dans le bois du tronc pourraient être liées à la ramification.

dimension radiale / unité structurale /Terminalia superba / arbre tropical / bois

\section{INTRODUCTION}

Some attention has been paid to growth phenomena in tropical trees. Morphological and morphogenetic studies on shoot growth have demonstrated the basic knowledge of continuous and flushing - or rhythmic growth and architectural models (Bond, 1942; 1945; Scarrone, 1965; Hallé and Martin, 1968; Borchert, 1969; Hallé and Oldeman, 1970; Greathouse et al, 1971; Vogel, 1975a,b; Hallé et al, 1978; Ng, 1979; Parisot, 1988; EJ-Morsy and Millet, 1989). Concerning secondary growth, there is some information on wood production and on the existence, anatomy and periodicity of growth rings in the wood of numerous species (Hummel, 1946; Mariaux, 1967; Lowe, 1968; Mariaux, 1969, 1970; Gill, 1971; Amobi, 1974; Détienne et Mariaux, 1975, 1976, 1977; Fahn et al, 1981; Mariaux, 1981; Zamski, 1981; Ash, 1983a, b; de Faÿ, 1985; Boninsegna et al, 1989; Détienne, 1989; Jacoby, 1989; Worbes, 1989). These data suggest various patterns of cambial growth among the trees of the intertropical zone. However, detailed studies on cambial activity, such as histophysiological investigations are still rare, fragmentary and generally concern mature trees growing intermittently, the wood of which displays annual growth rings (Lowe, 1968; Paliwal and Prasad, 1970; Lawton and Lawton, 1971; Rao, 1972; Amobi, 1973; Paliwal et al, 1976; Ghouse and Shamima Hashmi, 1979; Zamski, 1979; Rao and Dave, 1981; Rogers, 1981; Dave and Rao, 1982; Deshpande and Rajendrababu, 1985; Venugopal and Krishnamurthy, 1987). As regards correlations between growing organs, only relationships between leaf and shoot growth have been examined in a few tropical trees (Greathouse et al, 1971; Prévost, 1972; Borchert, 1973, 1978) and the effect of leaves on internode elongation has been demonstrated in Terminalia superba (Maillard et al, 1987b).

Young plants of the African species Terminalia superba Engl and Diels grown in a natural environment were studied within 
the context of research on growth rhythms and relationships between primary and secondary growths of the shoot system. $T$ superba is a forest species, the architecture of which has been characterized by Hallé and Oldeman (1970) as Aubréville's model. Its trunk is a monopode, the growth of which is assumed to be rhythmic and gives branches a pseudowhorled arrangement, commonly called a tier. Branches are sympodial and horizontal by apposition to spiral phyllotaxy units. Each sympodial unit is characteristic of the genus Terminalia, the Terminalia branching being specifically described in $T$ catappa (Hallé and Oldeman, 1970; Tomlinson and Gill, 1973; Fisher, 1978). The vegetative development of $T$ superba, at an early stage, has recently been studied under controlled conditions (Maillard, 1987; Maillard et al, 1987a,b; 1989). These authors determined the most favourable conditions for growth and considered growth periodicity. It appears that the trunk displays an alternation of long and short internode series, obvious at $27^{\circ} \mathrm{C}$ and under 14- or 16-h daylengths.

This paper reports a study on the spatial aspects of growth in a natural tropical environment. The purpose was not only to compare the vegetative development of young trees under natural and controlled environmental conditions, especially the formation of morphologically discrete growth increments (units of extension, Hallé et al, 1978), but also to increase the number of criteria which would allow the growth of Terminalia superba to be characterized. Trunk wood structure and size of axes were thus investigated. On the one hand, relationships between radial size of axes and number of branch modular components, ie sympodial units, were sought in addition to units of extension along trunks. On the other hand, histological investigations on trunk wood were aimed at finding structural variations in relation to units of extension, ie rhythmic growth rings (de Faÿ, 1985).

\section{MATERIALS AND METHODS}

The trees studied came from the experimental plantation of the Centre Technique Forestier Tropical on the Ivory Coast, located in the forest of Anguédédou, about $30 \mathrm{~km}$ north-west of Abidjan. A clonal plot was put at the author's disposal to study 5 trees. The trees were descended from stem cuttings that had been made from 3month-old shoots and had been planted 3 months later. They were aged 21 months when studied. A good size, well-separated tiers of branches and an absence of any trunk reiteration were the criteria for the choice of plants. The clonal origin was unknown at the time of se. lection, which should have ensured a certain variability among the chosen trees, as if seedlings had been studied. The 5 trees (TA-TE) were of the same geographic provenance, 2 were half-sibs (TA and TC) and 2 were of the same clone (TD and TE). The ground had been prepared, before planting, by manual cutting of the forest plot; the plant spacing was initially 2.5 $x 2.5 \mathrm{~m}$; manual weeding had been regular. Therefore, the $T$ superba trees were not growing in competition for light with other vegetation. They had been subjected to full sunlight.

As the species $T$ superba is disseminated throughout the evergreen rain forest in the south of the lvory Coast and it invades the secondary bush (Aubréville, 1959), the variability and local growing conditions of the trees studied were apparently similar to those of 'fraké' saplings - fraké is the local common name of this species - in a large chablis of the adjacent forest. The site is located in the intertropical zone at about $5^{\circ}$ latitude north, that is to say in the so-called 'humid tropics'. As in many tropical regions, the seasonal variations in temperature and solar radiation are not great, but the amount of rainfall is distributed irregularly. There are 2 dry seasons (December-March and mid July-September) alternating with 2 rainy seasons (April-mid July and mid September-November). Thus for more than one and a half years, the young trees had been subjected to a monthly temperature of $25-28{ }^{\circ} \mathrm{C}$ (Atlas de la Côte d'voire, 1978) and a photoperiod of 12.2-13.2 $\mathrm{h}$ daylength, allowing for dawn and dusk (Longman and Jenik, 1963), which is fairly close to the $27{ }^{\circ} \mathrm{C}$ and $14-\mathrm{h}$ daylength found to be the most favourable for the development of young $T$ superba trees under controlled conditions (Maillard et al, 1987a). However, they had lived through several dry seasons and the 
last one was just before the examination. The lack of rainfall could thus have restricted plant growth seasonally.

For observations and measurements, trunks were cut at the base, at the beginning of March, just after total new leafing of the plants, and were inspected immediately from base to apex. The relative position of leaf-scars, or leaves in the upper part only, was studied to find regions with short internodes or an alternation of long and shorter internode regions. The transition zones from long to short internode regions were marked to delimit units of extension. When the limit was not obvious, the middle of the shortest internode was taken into account to separate successive trunk segments, and these were measured. In addition, the number of tiers per unit, the number of branches per tier, the number of sympodial units per branch, the mean basal diameter of branches and the circumference of trunks at $5 \mathrm{~cm}$ above and below each tier, or in the middle of a unit with no branch, were recorded.

For histological studies of the wood, 2 kinds of sample were collected in the middle part of each unit of extension, beneath the tier of branches: discs and cores. Firstly, the 2-3-cm long discs were put into an air-conditioned room to dry; afterwards, they were treated with sodium hypochlorite to lighten them (Mariaux, 1969) and finely polished; they were observed with a stereomicroscope before and after treatment with phloroglucinol- $\mathrm{HCl}$, characterizing lignins (Sass, 1958). Secondly, the outermost trunk tissues, including wood, were sampled with a bone puncture surgical instrument and the cores were fixed in Craf 1 (Sass, 1958); they were then cut transversely with a freezing microtome, and the $40-\mu \mathrm{m}$ thick sections were stained with phloroglucinol-HCl and examined microscopically.

\section{RESULTS}

\section{Spatial variations in external structure and size of axes}

Typical units of extension, ie trunk segments, well-delimited by areas of more tightly packed leaf-scars, could not be ob- served along the trunks, except at the top; indeed, there was only a sharp limit at the base of the developing part, in 4 out of 5 trees. However, on the lower part, there were several areas with some relatively short internodes, compared with the adjacent regions. Variations in internodal length occurred progressively. It should be noted that a slight variation might pass unnoticed and, moreover, leaf-scars tended to become indistinct on the old parts of trunks. Nevertheless, trunk segments consisting of long internode series separated by shorter internode series could be distinguished (fig 1).

These poorly delimited segments generally bore one tier of branches located in the central part. However, 2 sets of branches were observed in 2 different segments and, in the basal segments, sometimes no branch was found (fig 1).

Concerning axis sizes, the circumference of trunks increased from apex to base but irregularly on each side of the developing tiers of branches. In addition, the basal diameter of branches was correlated positively with the number of component sympodial units (fig 2). A close relationship was also found between trunk circumference and the total number of sympodial units in the branches inserted above the level studied (fig 3).

\section{Structural variations in trunk wood}

The wood of the trunks showed slight concentric colour variations in polished transverse sections. A stereomicroscope highlighted numerous light irregular concentric bands on a comparatively dark background (figs 4A, B). These bands were paratracheal axial parenchyma of the confluent type. In general, band spacing varied gradually, increasing and decreasing alternately. The dark background of the 


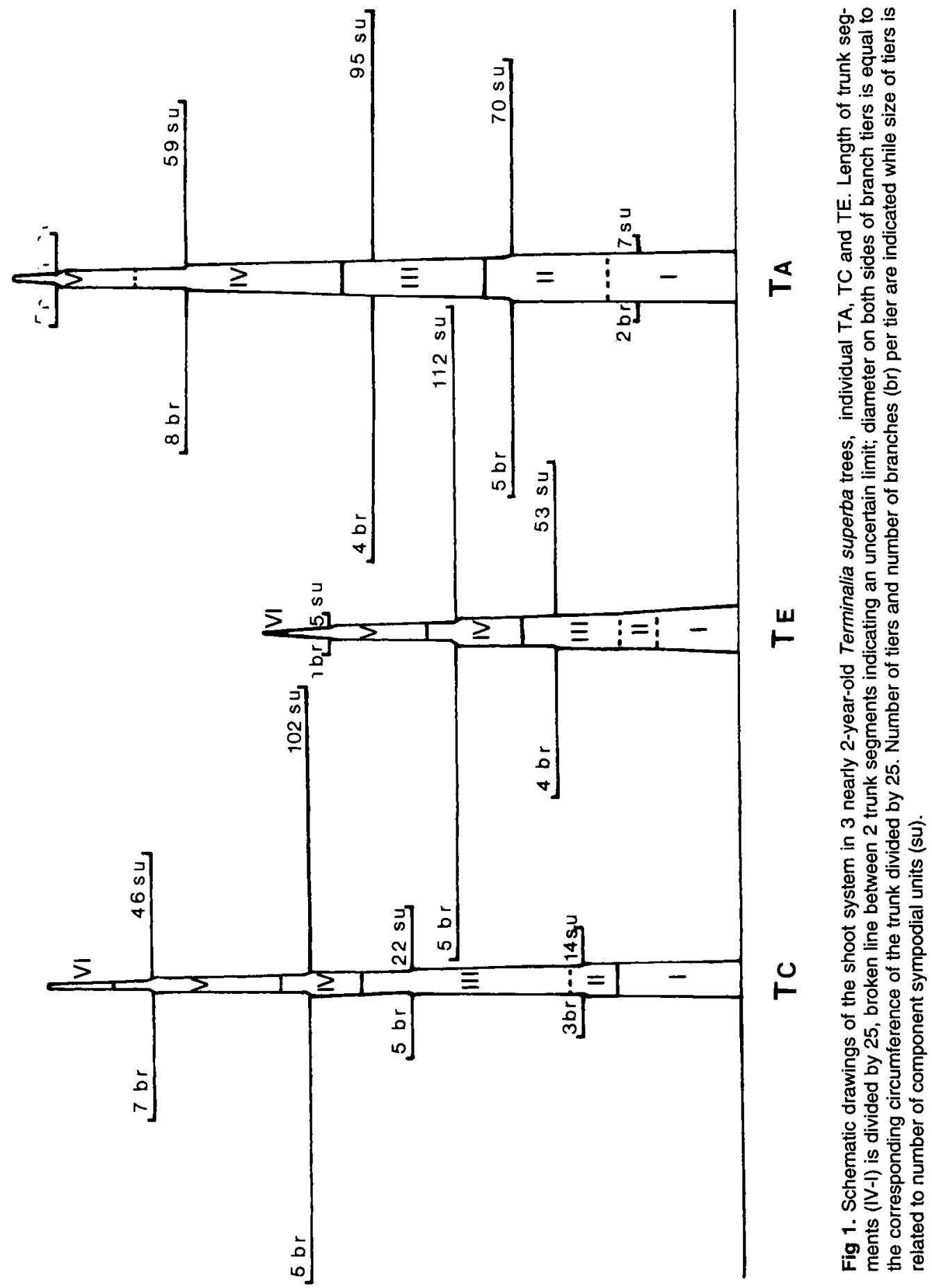




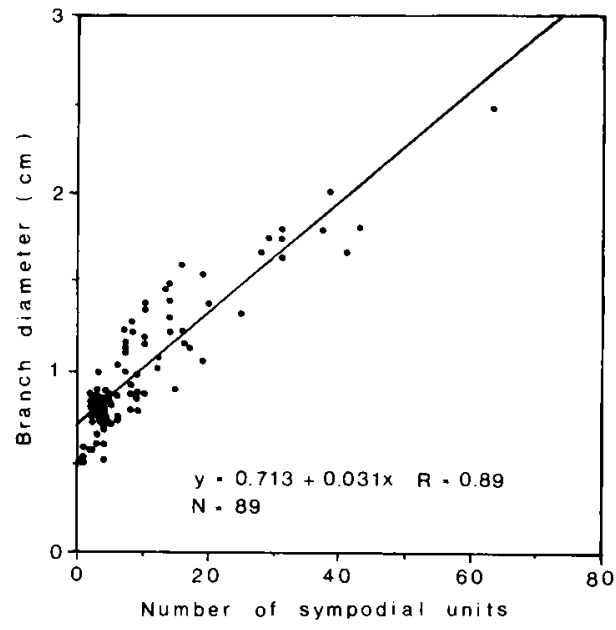

Fig 2. Relationship between basal diameter and number of component sympodial units in each branch of 5 young Terminalia superba trees.

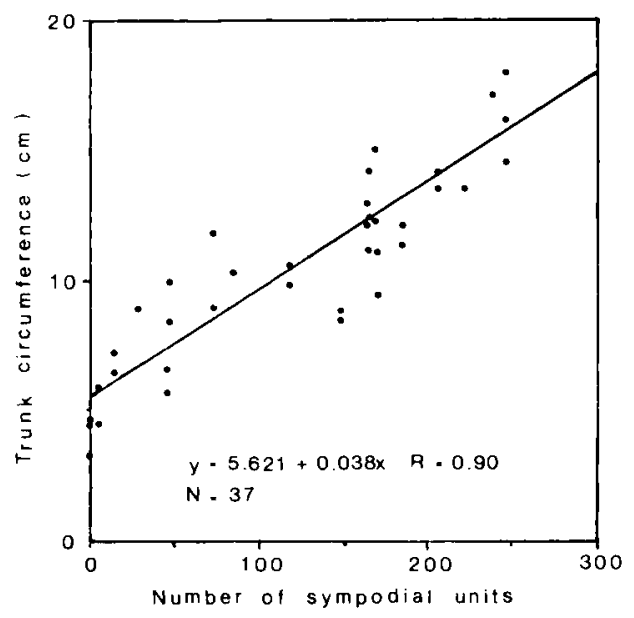

Fig 3. Relationship between trunk circumference at different levels, and total number of sympodial units in all the branches inserted above a given level, in 5 young Terminalia superba trees. polished transverse sections of wood consisted of wood fibres. Positive phloroglucinol- $\mathrm{HCl}$ tests showed wood fibres arranged in alternating concentric layers (fig $5 A)$. These variations resulted mainly from changes in the number of cells per unit area (fig 5B).

These 2 types of concentric and repeated variations - in the spacing of parenchyma bands and in the intensity of staining were not always closely correlated, especially in the lower trunk segments. Moreover, the thickness of wood layers varied strongly within a trunk section, particularly in the lower segments: a single wood layer was sometimes thick and sometimes thin; the different wood layers that were defined by the same feature had very different thicknesses, in the internal wood, whatever their position; the thickness of adjacent wood layers varied independently: for instance the wood layers with relatively narrow band spacing were sometimes thick and sometimes thin in comparison with the innermost ones with wider band spacing. The great structural variability in trunk wood made the wood layer count difficult. Several counts of the wood layers that were defined by variations in band spacing were made in each trunk sections (on the 2 polished areas), because a small local variation of band spacing could at first pass unnoticed. The results (table I) showed clearly that the number of wood layers increased basipetally but irregularly from one trunk segment to the next (older one) below.

The most recent wood layers (2-5 according to the trunk level) were distinguished from each other more easily: those with a wide spacing of parenchyma bands were thick, whereas those with narrow band spacing were thin; moreover, parenchyma bands were wider in the former than in the latter (figs $4 A, B$ ). The staining of the wood background following 

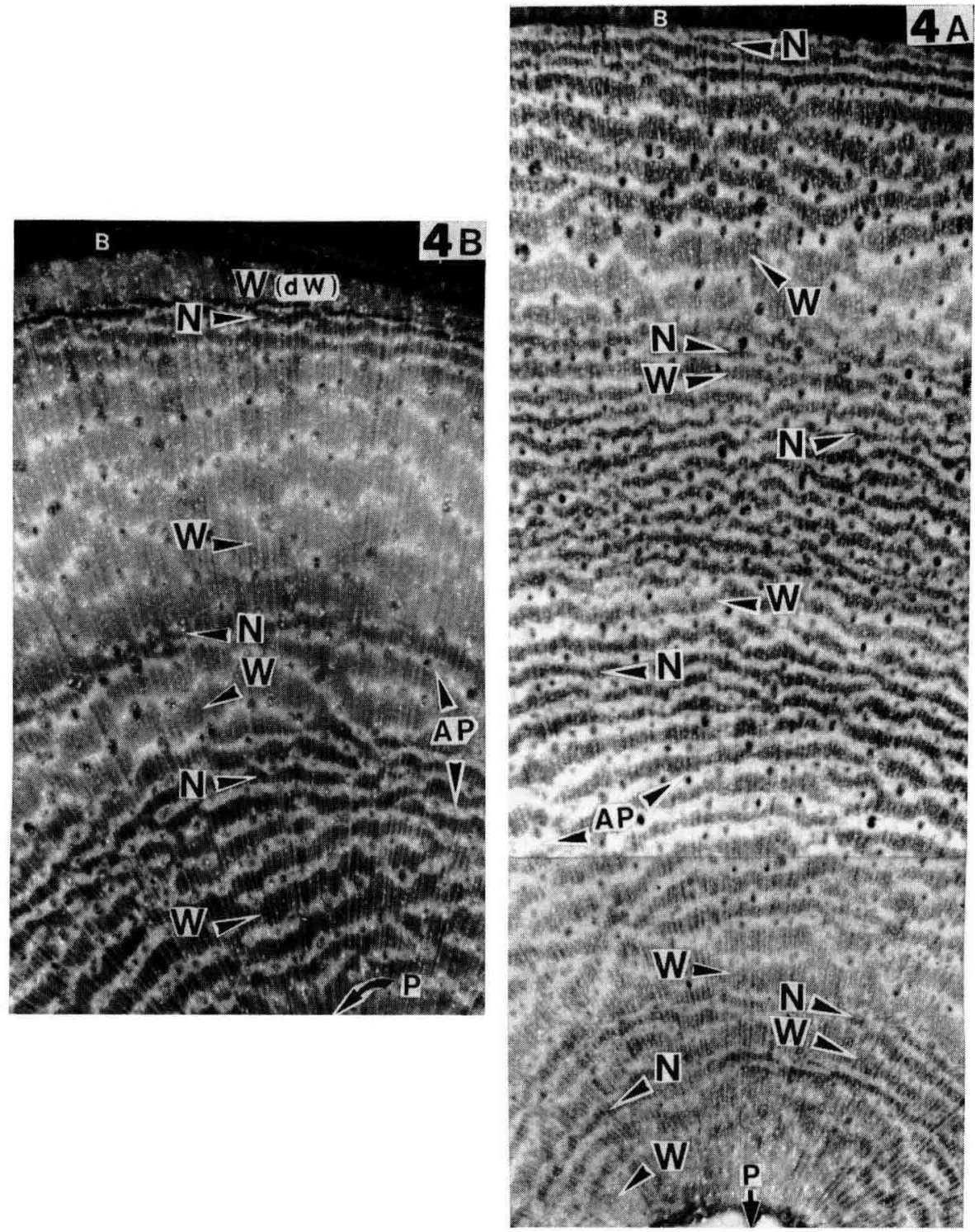

Fig 4. Polished transverse sections of the trunk in trunk segments II (4A) and IV (4B) of a nearly 2year-old Terminalia superba tree (individual TB). Observe the alternating concentric wood layers that are characterized by widely- or narrowly-spaced bands of axial parenchyma. The change in band spacing is particularly evident in peripheral wood. Note also the alternately dark and lighter background of wood formed by fibres. These 2 kinds of variation are often superimposed. The differentiating wood layer is found in the segment IV (4B) and is missing lower down, in the segment II (4A). 4A and $4 B \times 8$. Abbreviations: $A P$ : axial parenchyma (band of), $B$ : bark, $d W$ : differentiating wood, $N$ : relatively narrow spacing of parenchyma bands, $\mathrm{P}$ : pith, $\mathrm{W}$ : wider band spacing (than $\mathrm{N}$ ). 

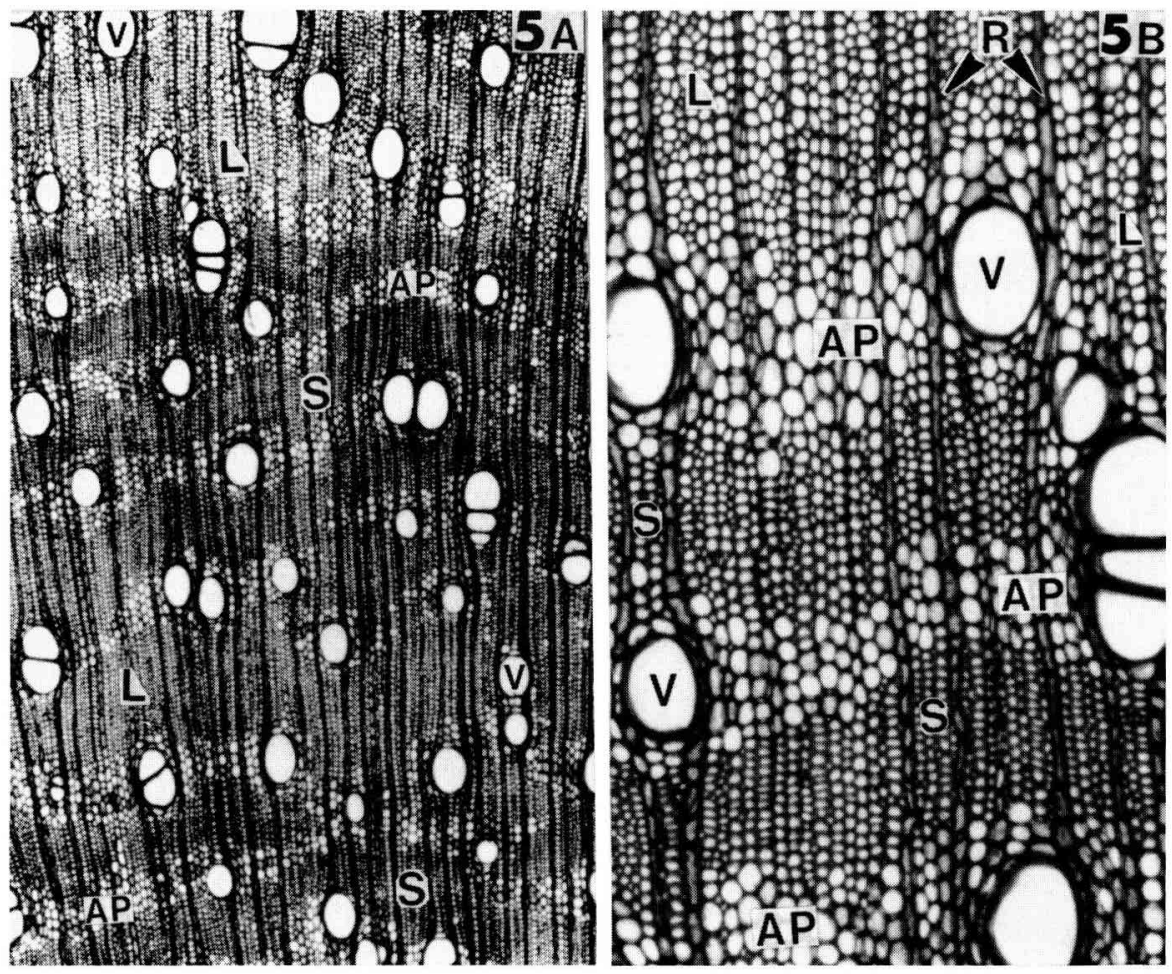

Fig 5. Transverse section of wood, stained by the phloroglucinol- $\mathrm{HCl}$ test indicating lignins (trunk segment III of the individual TB). 5A: Observe the alternation of strongly or slightly stained irregular wood layers. $\times$ 30. 5B: Detail showing that the difference in intensity of staining results particularly from the number of cells per unit area. Compare also the size of parenchyma cells in the parenchyma bands that are located in the vicinity of either flattened or dilated fibres. $x$ 90. Abbreviations: AP: axial parenchyma, L: less stained fibres (than S), R: ray, S: strongly stained fibres, V: vessel.

the phloroglucinol- $\mathrm{HCl}$ test was less intense in the wood layers with wide band spacing than in those with narrow band spacing. Variations in staining were gradual from one wood layer to another, except between the 2 most recent wood layers (fig 6A).

Indeed, the limit was sharp only between the 2 most recent wood layers. Histologically, this was the transition between strongly radially flattened, thick-walled fibres and younger radially dilated, thinner- walled fibres, the former belonging to the outermost wood layer that was defined by narrowly-spaced parenchyma bands and the latter to the differentiating wood which exhibited widely-spaced parenchyma bands (fig 6B). This boundary was not always uniform at the cellular level, mainly because of the occurrence of parenchyma bands. In this area, parenchyma cells changed from a radially flattened type to a radially dilated type - more precisely from a rather narrow area to a wider area in cross section (fig 
Table I. Number of wood layers with relatively narrowly-(N) and widely-(W) spaced parenchyma bands in the wood of different trunk segments I-V, beneath the branch tiers where they are found in 5 young Terminalia superba trees, individuals TA-TE. Notice that 2 samples were taken from trunk segment IV of TA and from trunk segment I of TD; a single sample was taken from below trunk segment III of TE. 5,7 and $5-7$ indicate that respectively 5 or 7 and 5,6 or 7 wood layers of 1 type were counted in a given sample.

\begin{tabular}{|c|c|c|c|c|c|c|c|c|c|c|}
\hline \multirow{3}{*}{$\begin{array}{l}\text { Trunk } \\
\text { segments }\end{array}$} & \multicolumn{10}{|c|}{ Terminalia superba trees } \\
\hline & \multicolumn{2}{|c|}{$T A$} & \multicolumn{2}{|c|}{$T B$} & \multicolumn{2}{|c|}{$T C$} & \multicolumn{2}{|c|}{$T D$} & \multicolumn{2}{|c|}{$T E$} \\
\hline & $N$ & $w$ & $N$ & $W$ & $N$ & $w$ & $N$ & $W$ & $N$ & $w$ \\
\hline \multirow{3}{*}{1} & \multirow{3}{*}{5,7} & \multirow{3}{*}{6,8} & \multirow{3}{*}{$5-7$} & \multirow{3}{*}{$6-9$} & \multirow{3}{*}{6} & \multirow{3}{*}{6} & 5 & 6 & & \\
\hline & & & & & & & & & & \\
\hline & & & & & & & 4 & 5 & 6 & 5 \\
\hline ॥ & 3 & 4 & 6 & 6,7 & 5 & 5 & 2 & 3 & & \\
\hline III & 2 & 3 & 5 & 6 & 4 & 5 & 1 & 2 & 4 & 3 \\
\hline \multirow{3}{*}{ IV } & 2 & 3 & \multirow{3}{*}{3} & \multirow{3}{*}{4} & \multirow{3}{*}{4} & \multirow{3}{*}{5} & & & & \\
\hline & & & & & & & \multirow{2}{*}{\multicolumn{2}{|c|}{$\begin{array}{l}\text { Developing } \\
\text { segment }\end{array}$}} & 4 & 3,4 \\
\hline & 2 & 3 & & & & & & & & \\
\hline v & \multicolumn{2}{|c|}{$\begin{array}{l}\text { Developing } \\
\text { segment }\end{array}$} & 1 & 2 & 1 & 2 & & & 1 & 2 \\
\hline VI & & & \multicolumn{2}{|c|}{$\begin{array}{l}\text { Developing } \\
\text { segment }\end{array}$} & \multicolumn{2}{|c|}{$\begin{array}{l}\text { Developing } \\
\text { segment }\end{array}$} & & & \multicolumn{2}{|c|}{$\begin{array}{l}\text { Developing } \\
\text { segment }\end{array}$} \\
\hline
\end{tabular}

$6 \mathrm{~B})$ - and vessels from small, thick-walled pores to large, relatively thin-walled pores (fig 6A). The microscopical examination did not indicate noticeable changes in wall staining. Histological differences between wood layers with narrow and wide spacings of parenchyma bands tended to be less visible in internal wood (figs 4A, $B, 5 A$, $B)$. The developing wood layer was found in the 5 trunks studied, but its thickness decreased basipetally and it could be partially formed or totally missing in the base of the trunk (figs $4 A, B$ ).

\section{DISCUSSION}

The trunk of young $T$ superba trees grown in a natural environment was characterized by alternating series of long and shorter internodes, as in a controlled environment chamber (Maillard et al, 1987a), which generally formed poorly-delimited units of extension. The vaguely segmented structure of the trunk was confirmed at the wood level. The spacing of parenchyma bands, the radial enlargment of wood fibres and parenchyma cells, the wall thickness of wood fibres and to a lesser extent the width of parenchyma bands, the pore size and wall thickness of vessels changed in such a way that wood layers were suggested to be alternately more and less dense. The changes were generally gradual and apparently bore no relation to the development of the units of extension. Thus, there were no rhythmic growth rings in the juvenile wood of $T$ superba, unlike 


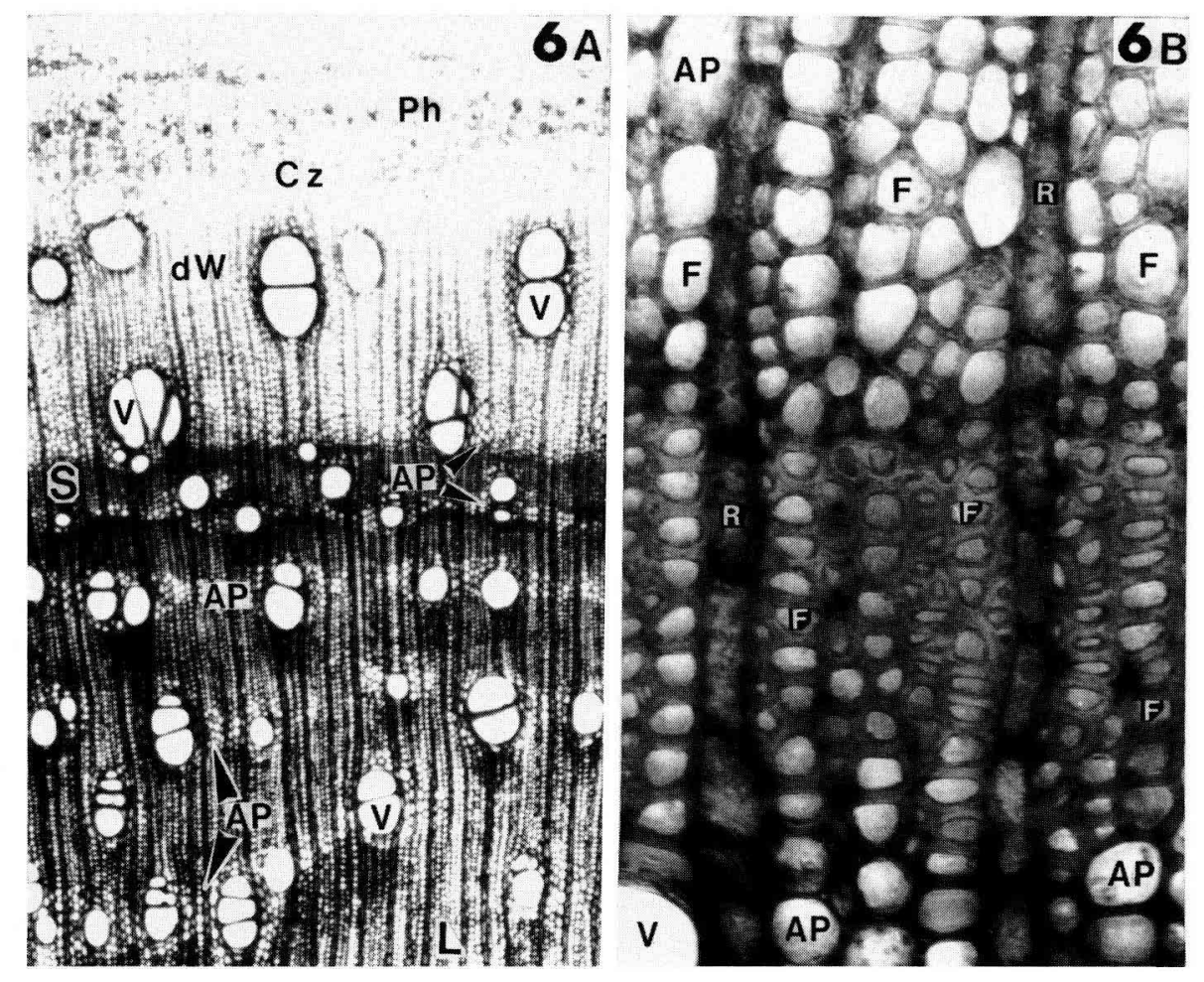

Fig 6. Transverse section of trunk peripheral tissues, stained with phloroglucinol- $\mathrm{HCl}$ (trunk segment $V$ of individual TB). 6A: Strong staining of the wood layer with narrowly-spaced parenchyma bands contrasts with slight staining of the differentiating wood layer with widely-spaced parenchyma bands. Compare also the size of vessels. $\times 30$. 6B: Detail showing the obvious boundary between flattened thick-walled fibres and younger dilated thin-walled fibres. The change in size of parenchyma cells is also visible. $\times 360$. Abbreviations: AP: axial parenchyma, $\mathrm{Cz}$ : cambial zone, dW: differentiating wood, F: fibre, L: less stained fibres (than S), Ph: phloem, R: ray, S: strongly stained fibres, V: vessel.

that of Hevea brasiliensis (de Faÿ, 1985; 1986). In short, structural units of the Hevea type, characteristic of the rhythmic growth-habit were found neither externally along the trunk nor in trunk wood.

Nevertheless, the structural variations in wood could indicate that the cambial growth of trunks was alternately rapid and slow, especially since structural variations of that nature are visible within the growth rings of some mature tropical trees (Mariaux, 1967; Boninsegna et al, 1989; Détienne, 1989; Vetter and Botosso, 1989; Worbes, 1989). In fact, the abrupt (spatial) variations of trunk thickness were related to the upper tiers of branches and there was a close relationship between trunk thickness and size of branches (in number of modules) that were inserted above the level studied. Moreover, trunk segments 
that were defined by variations in internodal length usually bore 1 tier of branches. These data indicate trunk-branch correlations and imply that some structural variations in trunk wood could be related to branching. Indeed, the leaves of developing axes are assumed to produce the stimuli (phytohormones) that induce the differentiation of wood (Aloni, 1989).

Climatic variations could also have had repercussions on wood formation, especially the lack of rainfall, as in the wood of Carya glabra where the spacing of tangential parenchyma bands is related to the rate of rainfall (Hill, 1982). At any rate, the outer structural discontinuity in the trunk wood of the trees studied could be related to a seasonal change, at least in phenology. Indeed, initiation of the basipetally developing wood layer was associated in time with the bud break (this had begun 2 weeks before sampling and had followed the totally leafless period occurring at the end of the long dry season). Reduction or absence of the developing wood layer at the base of trunks should indicate a delay in the resumption of cambial activity, because of the basipetal decrease in leaf hormone stimulation (Aloni, 1989). The peripheral structural discontinuity in trunk wood should be the sign of a rest during the totally leafless period when the trees were almost 2 years old. It should be pointed out that some younger $T$ superba plants growing in the same climate showed low or no radial increments, or trunk shrinkage in February, ie at the end of the long dry season (de Faÿ, 1992). Wood differentiation in the trunks of young $T$ superba plants could thus be altered by drought or other causes of internal water deficit.

In conclusion, the trunk of young $T$ superba tropical trees grown in a natural environment did not have the typical features of flushing species, such as Hevea brasiliensis (Hallé and Martin, 1968; de Faÿ, 1985), Theobroma cacao (Greathouse et al, 1971; Vogel, 1975a, b; de Faÿ, unpublished results) or Quercus robur (Payan, 1982; Champagnat et al, 1986). These results on spatial variations in structure and size of axes indicate trunk-branch correlations rather than typical units of extension along the trunk and rhythmic growth rings in trunk wood. A subsequent study of temporal aspects of growth in young $T$ superba trees in the same natural environment (de Faÿ, 1992) has already given results in accordance with the present data. It is thus suggested that the 'pagoda' architecture of Terminalia superba resulted more from the periodicity of branching than from a flushing growth of trunk, at least in the early stage.

\section{ACKNOWLEDGMENTS}

The author is grateful to the late Director of the Centre Technique Forestier Tropical on the Ivory Coast, Dr K Diabate and his colleagues for providing plant material and Professor JM Favre (University of Nancy I) for his critical reading of the manuscript.

\section{REFERENCES}

Aloni R (1989) Control of xylogenesis within the whole tree. Ann Sci For, 46 suppl 267s-272s

Amobi CC (1973) Periodicity of wood formation in some trees of lowland rainforest in Nigeria. Ann Bot 37, 211-218

Amobi CC (1974) Periodicity of wood formation in twigs of some tropical trees in Nigeria. Ann Bot 38, 931-936

Ash $\mathrm{J}$ (1983a) Growth rings in Agathis robusta and Araucaria cunninghamii from tropical Australia. Austr J Bot 31, 269-275

Ash J (1983b) Tree rings in tropical Callitris macleayana F Muell. Aust J Bot 31, 277-281

Aubréville A (1959) La Flore Forestière de la Côte d'lvoire. Centre Tech For Trop, Nogent sur Marne, France, vol 3

Bond TET (1942) Studies in the vegetative growth and anatomy of the tea plant (Camel- 
lia thea Link) with special reference to the phloem. I. The flush shoot. Ann Bot 6, 607629

Bond TET (1945) Studies in the vegetative growth and anatomy of the tea plant (Camellia thea Link) with special reference to the phloem. II. Further analysis of the flushing behaviour. Ann Bot 9, 183-216

Boninsegna JA, Villalba R, Amarilla L, Ocampo $J(1989)$ Studies on tree rings, growth rates and age-size relationships of tropical tree species in Misiones, Argentina. IAWA Bull 10, 161-169

Borchert R (1969) Unusual shoot growth pattern in a tropical tree Oreopanax (Araliaceae). Am J Bot 56, 1033-1041

Borchert R (1973) Simulation of rhythmic tree growth under constant conditions. Plant Physiol 29, 173-180

Borchert R (1978) Feedback control and age related changes of shoot growth in seasonal and nonseasonal climates. In: Tropical Trees as Living Systems (Tomlinson PB, Zimmermann $\mathrm{MH}$, eds) Cambridge Univ Press, 497515

Champagnat $P$, Payan $E$, Champagnat $M$, Barnola P, Lavarenne S, Bertholon C (1986) La croissance rythmique de jeunes chênes pédonculés cultivés en conditions contrôlées et uniformes. Coll Int sur l'Arbre. Nat Monspeliensia, 303-337

Dave YS, Rao KS (1982) Seasonal activity of the vascular cambium in Gmelina arborea Roxb. IAWA Bull 3, 59-65

Deshpande BP, Rajendrababu $T$ (1985) Seasonal change in the structure of the secondary phloem of Grewia tiliaefolia, a deciduous tree from India. Ann Bot 56, 61-71

Détienne P (1989) Appearance and periodicity of growth rings in some tropical woods. IAWA Bull 10, 123-132

Détienne $P$, Mariaux A (1975) Nature et périodicité des cernes dans le bois de Niangon. Bois For Trop 159, 29-37

Détienne $P$, Mariaux A (1976) Nature et périodicité des cernes dans le bois de Samba. Bois For Trop 169, 29-34

Détienne P, Mariaux A (1977) Nature et périodicité des cernes dans les bois rouges de Méliacées africaines. Bois For Trop 175, 5261
El-Morsy AA, Millet B (1989) Analyse de la croissance rythmique du mandarinier commun (Citrus deliciosa Tenore) cultivé en conditions constantes. Fruits 44, 21-27

Fahn A, Burley J, Longman KA, Mariaux A, Tomlinson PB (1981) Possible contributions of wood anatomy to the determination of age of tropical trees. In: Age and Growth Rate of Tropical Trees: New Directions for Research (Bormann FH, Berlyn G, eds) Yale Univ, New Haven, CT, 31-54

Faÿ E de (1985) Recherche de marqueurs du mode de croissance cambiale chez Hevea brasiliensis (Euphorbiaceae) : les anneaux de croissance rythmique du bois juvénile. Bull Mus Nat Paris 4th sér 7, sect B; Adansonia 2, 139-154

Faÿ E de (1986) Mode de croissance cambiale de quelques arbres tropicaux au stade juvénile. Coll Int sur l'Arbre. Nat Monspeliensia 13-27

Faÿ E de (1992) Vegetative development, primary and secondary growth of the shoot system of young Terminalia superba tropical trees, in a natural environment. II. Terminal growth, lateral growth and main stem-branch growth correlations. Ann Sci For 49, 403-422

Fisher JB (1978) A quantitative study of Terminalia branching. In: Tropical Trees as Living Systems (Tomlinson PB, Zimmermann MH, eds) Cambridge Univ Press, 285-320

Ghouse AKM, Shamina Hashmi (1979) Cambium periodicity in Polyalthia longifolia. Phytomorphology 29, 64-67

Gill AM (1971) Endogenous control of growth ring development in Avicennia. For Sci 17, 462-465

Greathouse DC, Laetsch WM, Phinney BO (1971) The shoot-growth rhythm of a tropical tree, Theobroma cacao. Am J Bot 58, 281. 286

Hallé F, Martin R (1968) Étude de la croissance rythmique chez l'Hévéa (Hevea brasiliensis Müll-Arg Euphorbiacées-Crotonoidées). Adansonia 2 (8), 475-503

Hallé F, Oldeman RAA (1970) Essai sur l'Architecture et la Dynamique de Croissance des Arbres Tropicaux: Monogr Bot et Biol Vég. Masson, Paris

Hallé F, Oldeman RAA, Tomlinson PB (1978) Tropical Trees and Forests - An Architectural Analysis. Springer Verlag, Heidelberg 
Hill JF (1982) Spacing of parenchyma bands in wood of Carya glabra (Mill) sweet, pignut hickory, as an indicator of growth role and climate factors. Am J Bot 69, 529-537

Hummel FC (1946) The formation of growth rings in Entandrophragma macrophyllum A Chev and Khaya grandifoliola CDC. Emp For Rev 25, 103-107

Jacoby GC (1989) Overview of tree-ring analysis in tropical regions. IAWA Bull 10, 99-108

Lawton JR, Lawton JRS (1971) Seasonal variations in the secondary phloem of some forest trees from Nigeria. New Phytol 70, 187196

Longman KA, Jenik J (1963) Tropical Forest and Its Environment. Longmans, New York

Lowe RG (1968) Periodicity of a tropical rain forest tree Triplochiton scleroxylon K Schum. Commonw For Rev 47, 150-163

Maillard P (1987) Étude du développement végétatif du Terminalia superba Englers et Diels en conditions contrôlées : mise en évidence de rythmes de croissance. Thesis, Univ Paris VI, France

Maillard $P$, Jacques $M$, Miginiac $E$, Jacques $R$ (1987a) Croissance de jeunes Terminalia superba Englers et Diels en conditions contrôlées. Ann Sci For 44, 67-83

Maillard $P$, Jacques M, Miginiac E (1987b) Correlative growth in young Terminalia superba in a controlled environment: effect of the leaves on internode elongation. Ann Sci For $60,447-454$

Maillard $P$, Jacques $M$, Miginiac $E$, Millet $B$ (1989) Mathematical analysis and comparison of growth fluctuations of the aerial system of young Terminalia superba Englers et Diels (Combretaceae). Ann Sci For 46 suppl; Forest Tree Physiology (Dreyer $E$ et al, eds) Elsevier, INRA, 202s205s

Mariaux A (1967) Les cernes dans les bois tropicaux africains, nature et périodicité. Bois For Trop 113, 3-14; 114, 23-37

Mariaux A (1969) La périodicité des cernes dans le bois de Limba. Bois For Trop 128, 39-54

Mariaux A (1970) La périodicité des cernes dans le bois de l'Okoumé. Bois For Trop 131, $37-50$
Mariaux A (1981) Past efforts in measuring age and annual growth in tropical trees. In: Age and Growth Rate of Tropical Trees: New Directions for Research (Bormann FH, Berlyn G, eds) Yale University, New Haven, CT

Ng FSP (1979) Growth rhythms in tropical juvenile trees. Bull Soc Bot Fr 126; Actua Bot 139-149

Paliwal GS, Prasad NSRK (1970) Seasonal activity of cambium in some tropical trees I Dalbergia sissoo. Phytomorphology 20, 333339

Paliwal GS, Saiwan VS, Shashi Kanta Aggarwal (1976) Seasonal activity of cambium in some tropical trees II Salvadora persica. Act Soc Bot Polon 45, 303-311

Parisot E (1988) Étude de la croissance rythmique chez de jeunes manguiers (Mangifera indica L). Fruits 43, 97-312

Payan E (1982) Contribution à l'étude de la croissance rythmique chez les jeunes chênes pédonculés (Quercus pedonculata Ehrh). Thesis, Univ Clermont-Ferrand, France

Prévost MF (1972) Rythme d'allongement des articles de Tabernaemontana crassa Benth (Apocynacées). Candollea 27, 219-227

Rao AN (1972) Periodic changes in the cambial activity of Hevea brasiliensis. I Indian Bot Soc 51, 13-17

Rao KS, Dave YS (1981) Seasonal variations in the cambial anatomy of Tectona grandis (Verbenaceae). Nord J Bot 1, 535-542

Rogers $S$ (1981) Seasonal variation in radial growth and phloem activity in Terminalia ivorensis A Chev. Ann Bot 47, 603-610

Sass JE (1958) Botanical Microtechnique. The lowa State University Press, Ames, IA

Scarrone F (1965) Rôle respectif des rythmes endogènes et des facteurs climatiques dans la croissance du Manguier (Mangifera indica L). CR Acad Sci Paris 260, 3469-3472

Tomlinson PB, Gill AM (1973) Growth habits of tropical trees: some guiding principles. In: Tropical Ecosystems in Africa and South America: A Comparative Review (Meggers BJ, Ayensu ES, Duckworth, WD, eds) Smithsonian Inst Press, Washington, DC

Vennetier $P$ (ed) (1978) Atlas de la Côte d'Ivoire. Jeune Afrique, Paris 
Venugopal N, Krishnamurthy KV (1987) Seasonal production of secondary phloem in the twigs of certain tropical timber trees. Ann Bot 60, 61-67

Vetter RE, Botosso PC (1989) Remarks on age and growth rate determination of Amazonian trees. IAWA Bull 10, 133-146

Vogel M (1975a) Croissance rythmique du cacaoyer. Thesis, Univ Paris XI, Orsay

Vogel M (1975b) Recherche du déterminisme du rythme de croissance du cacaoyer. Café Cacao Thé 19, 265-290
Worbes M (1989) Growth rings, increment and age of trees in inundation forests, savannas and a mountain forest in the Neotropics. IAWA Bull 10, 109-122

Zamski $E$ (1979) The mode of secondary growth and the three dimensional structure of the phloem in Avicennia. Bot Gaz 140, 6776

Zamski E (1981) Does successive cambial differentiation in Avicennia depend on leaf and branch initiation? Israe/ J Bot 30, 57-64 